\title{
Linkages To Bookkeeping Training, Business Scale, Financial Records With The Members Participation of The Indonesian Women's Cooperative
}

\author{
Endang Sungkawati \\ Faculty of Economic and Business, \\ Wisnuwardhana University Malang-Indonesia \\ Budi Prawoto \\ Faculty of Economic and Business, \\ Wisnuwardhana University Malang-Indonesia \\ Klemens Mere \\ Faculty of Economic and Business, \\ Wisnuwardhana University Malang-Indonesia
}

\begin{abstract}
Knowledge of financial analysis, especially for business activity is essential, because by having that knowledge that the members of Micro Small Enterprises (MSE) will be able to record their business finances and can distinguish business finance, business capital, and personal finance. This is happening in the agents who become a member of the Indonesia Women Cooperative. The subject, in general, do not have the knowledge and ability to record and analyze the business. So they have difficulty in fulfilling their obligations and less participates in cooperative activities. Based on this, this study aims to: know the effect of bookkeeping training and business scale on member participation moderated by financial records. The results showed that the variable financial recording is a moderating variable in influencing the bookkeeping training and business scale on the participation of members of the Indonesia Women Cooperative.
\end{abstract}

Key Word: Bookkeeping Training, Business Scale, Financial Records, Member Participant

\section{INTRODUCTION}

Cooperatives need the support of active participation of members either in the capital, giving advice, or utilizing cooperative business services. However, the business undertaken by this cooperative does not always run well as expected. When cooperative members grow, the cooperative has to develop its business with its own resources. Therefore it is not easy to direct and guide all members to participate actively in accordance with the expectations of the cooperative.(Huang, Zazale, Othman, Aris, \& Ariff, 2015)

One of the important problems that exist in the cooperative is the participation of cooperative members. Members' participation is an important issue to be considered in the cooperative sector (Birchall \& Simmons, 2004). There are significant differences in member participation, which makes members play a key role in the success and failure of cooperatives because members also participate who contribute financially to support cooperative activities (Osterberg \& Nilsson, 2009). A strong membership base is a foundation for the success of a cooperative. It has supported this by stating that the new perspective of the cooperative movement in strong membership contributes to the growth of cooperative performance (Harun \& Mahmood, 2012). It explained that members become the starting point that 
determines the process of participation (Hendar \& Kusnadi, 2009). The role of members as cooperative owners requires them to participate in providing information, capital contribution, determining the programs that must be implemented by the management and oversee the course of the cooperative. Participation from members is vital for the growth of cooperatives in Malaysia (Aini, Hafizah, Zuraini, \& Y, 2012). The role of members as users of cooperative services requires members to participate in the use of business services in accordance with its type.

The findings of research conducted by (Bambang Banu, 2010) empirically stated that member cooperative knowledge significantly affects member participation. Co-operative education helps people to understand what co-operatives are and how they can participate more effectively in them. The course experience shows that fundamental values like ethics and solidarity are determinant to the success of technical cooperation processes (Castro, Vilar, \& Medeiros, 2015). These findings support the results of (Georgellis, Y; Joyce, P; Woods, 2000), (Nurlela Kataren, 2006), (Constantinescu, 2015), (Figueiredo \& Franco, 2018) which stated that there is a real relationship between formal and non-formal education members with the success of cooperatives and learning processes have a positive effect on member's ability and member participation. While the results of (Regts, 2009) stated that the knowledge of members directly affects the loyalty of members, it meant that their knowledge about the cooperative influenced the commitment of members.

Amini \& Ramezani (2008) found that members' participation in cooperative administration at a medium level did affect the success of cooperatives. This study also found that members' participation depends upon the age and education of the members, their level of investments, the usefulness of the cooperative to members, and their technical skills. While the results of research conducted by (Aufar, 2013) and (Kristiansen S., 2003) stated that the education of micro, small, medium business owners influenced their perception about the importance of financial bookkeeping and reporting as well as the use of accounting information. The participation of members in the cooperative means to include members of the cooperative in operational activities and the achievement of common goals (Hendar \& Kusnadi, 2009). Other researchers found that farmers' participation behavior is closely related to their perceptions of professional operatives and that educational attainment influences the farmers' perception level (Zheng et al., 2012).

Participation is the most important factor in supporting the success or development of an organization. Through participation, all aspects related to the implementation of activities can be completed. All programs that must be implemented by management need support from all elements or components that exist within the organization. From the above understanding can be concluded that without the participation of members, cooperatives will not be able to work effectively and efficiently. For that reason, participation is regarded as one of the most important things in cooperative life.

Likewise, with the cooperative of the Indonesia Women Cooperative, in which the cooperative also wants the active participation of members so that the cooperative can run according to its purpose, namely the welfare of members. But in reality, as a cooperative consisting of micro business workers, there are still many cooperative members who have not participated actively. There are still problems at the level of participation of members, such as 1) Based on the financial statements of the cooperative, some members who have small productive businesses are often late and not even pay their obligations to the cooperative; 2) As a small micro-business worker, members of the women cooperative do not have a good bookkeeping system, so the amount earned, the amount of profit, the amount for capital turnover, etc., are 
not well defaced, so that small micro-enterprise workers struggle when fulfilling the obligations of the cooperative; and 3) Micro small business workers do not record well to distinguish personal money, business capital, or profits. This problem will affect the participation of members and indirectly will also affect the growth of cooperatives. This study aims to answer: do bookkeeping training, business scale, and financial records affect the participating members of the Indonesia Women Cooperative? To determine the effect, this study was done by using a quantitative approach.

\section{Bookkeeping Training}

\section{LITERATURE REVIEWER}

Education and training of cooperative members are important in cooperative's co-operation and development because its success or failure depends on members' participation. To give a positive impact, the involvement of members in cooperative business activities must be done; besides, it is also the role of members within the organizational structure. Therefore, education and training are necessary to provide sufficient supplies to members, so that members can play an active and dynamic role.

The meaning of education itself is an activity to improve a person's general knowledge including the improvement of mastery of theory and skills in making decisions about the issues concerning activities to achieve goals (Sungkawati \& Hendrawaty, 2018). While, according to member education is an education to instill positive character such as diligent nature, unyielding, actively innovate, solidarity with others, as well as other characteristics needed for progress, as well as education to improve the insight and expertise of members in managing the cooperative (Sungkawati \& Suarniati, 2009). Further, (Hassan \& Prakash, 1990) state that the education of cooperative members is a process of transferring cooperative knowledge and materials related to cooperative members, administrators, regulatory affairs, cooperative employees, community leaders, prospective members, and community.

Cooperative education both formal and informal is the whole process of developing the ability or skills and human behavior that is done in an organized way and continuously and designed to combine the combination of knowledge, skills, and understanding in the field of cooperatives that is beneficial to all socio-economic activities of society (Sungkawati, Prawoto, \& Mere, 2018). As an informal education, cooperative member education can be interpreted as a process of transferring cooperative knowledge as well as matters relating to the ins and outs of the cooperative (Sinaga, 2015).

Based on the above opinion, it can be concluded that education for cooperative member is a process of transferring knowledge of cooperatives and planting positive nature that is done continuously to cooperative members, managers, regulatory affairs, cooperative employees, community leaders, prospective members, and general public, so they have insight and expertise in managing cooperatives. In this study, what is meant by bookkeeping training is training on bookkeeping gave to members of the cooperative as small micro business workers covering the process of training, its frequency, the material, its target group, its executor and the objectives to be achieved.

\section{Business Scale}

Understanding the business scale is to describe the size of a company shown by total assets, total sales, average total sales, and average total assets. So the size of the company is the size or amount of assets owned by the company (Pinasti, 2001). The scale of business is the ability of the company in managing its business by looking at how many employees are hired and how 
much revenue the company earned in one accounting period. The amount of income or sales generated by a micro-small business can indicate the asset turnover or capital owned by the business, so the higher the income or sales obtained, the greater the complexity of micro, a small business in recording its financial transactions. The number of employees can show how much capacity the company in operationalize business, the higher the number of employees, the greater the level of corporate complexity so that accounting information is needed.

In some countries, the definition of a small-scale enterprise is bound by financial measures such as net profits, balance sheet totals, the value of assets, and annual sales. In the United States, for example, a non-manufacturing small-scale enterprise is one that does not earn more than $\$ 7$ million in a year. Financial measures can vary by industry, as annual receipts may be higher for industries that have higher overhead costs to operate. In general, small-scale enterprises are businesses that do not dominate their respective industries.

Based on Law Number 20 the Year of 2008 regarding Micro, Small and Medium Enterprises, there are several criteria used to define the Definition and principles of Micro, Small, and Medium Enterprises. The explanation is:

a. Micro Business is a productive business owned by an individual(s) and business entities that fulfill the criteria of Micro Businesses as regulated in this Law.

b. Small business is a stand-alone productive economic business undertaken by an individual(s) or business entity that is not a subsidiary or not a branch of a company owned, controlled, or becomes part of the direct or indirect business of a medium-sized or large-scale business that meets the criteria Small Business as referred to in the Law.

c. Medium businesses a stand-alone productive economic enterprises, carried out by individual(s) or business entities that is not subsidiaries or branches of a company owned, controlled, or become part of, directly or indirectly, by a small business or a large business with a net worth amount or annual sales proceeds as stipulated in the Act.

\section{Financial Records}

Doing financial recording for someone who owns a business, even though in a small or micro business group, it is very helpful to see the profit and loss of the business. Creating a good financial report will help to distinguish personal money with business money and know the progress of the business.it does not need to be complicated in counting the small business needs, just by simple bookkeeping. The important thing is the willingness to manage the finances well.

The benefits of orderly bookkeeping (though micro-scale business) is to know the finances of the undertakings, the costs, and the decision-making. By looking at the financial data, an entrepreneur can see that his business is expanding and requires expansion. But, on the contrary, if the business turns out to be a loss, then the right decision can be made, whether it is maintained or closed so that the losses are not getting worse. Decision-making is based on financial statements, which is one of the information (Pinasti, 2001). Another benefit of bookkeeping is when a business wants to expand; it must be related to a third party. That is related to business capital. Financial statements are also indispensable when applying for credit to the bank. "The bank will see whether the business is bankable or not. One of the factors is from the financial statements. It can be deduced the importance of bookkeeping in running a business, no matter how small or big any business. If the business has an orderly cash flow record, then the financial condition of the business will be known. Thus it can be said that bookkeeping is useful to understand and manage the income and expenses incurred. 


\section{Member Participation}

(Sungkawati et al., 2018) States that the participation of members in the cooperative means to include its members in operational activities and in achieving common goals. Participation is the most important factor in supporting the success or development of an organization. Through participation, all aspects related to activities to achieve goals can be done. All programs that must be implemented by management need to get support from all elements within the organization. From the above understanding, it can be concluded that without the participation of members, a cooperative will not be able to work effectively and efficiently. For that reason, participation is regarded as one of the most important things in the cooperative.

The participation of members in the cooperative is classified into three: 1) Participation in capital to finance the growth of the cooperative, financial contributions in the form of principal savings, mandatory savings, voluntary savings as well as those of members' own business (participation of financial contributions) are indispensable; 2) Participation in the form of decision-making process regarding the determination of the purpose and policy, and the process of supervision of the cooperative must involve members as the owner of the cooperative (participation of members in the decision-making member); and 3) Participation in the utilization of business services is done to support the growth of cooperatives, members as customers/users must take advantage of every service provided by the cooperative (Hendar \& Kusnadi, 2009). The more members take advantage of cooperative services, the more benefits a member gets. When this happens, awareness in the implementation of contributive participation will increase (participation incentives).

Member participation is measured by the availability of members to do duties and rights with full responsibility. Indicated that the characteristics of the participating members can be formulated as follows: 1) Paying off the principal and compulsory savings in an orderly and orderly manner; 2) Assist the capital of the cooperative in addition to the principal savings and obligatory in accordance with their respective capabilities; 3) Become a loyal customer of the cooperative; 4) Attend meetings actively; and 5) Use the right to oversee the course of a cooperative effort, comply with the Articles of Association and the Household, other regulations and other common decisions (Regts, 2009)

In addition to education, other factors that affect the importance of bookkeeping is the business scale. The impact of business scale on the need for financial recording for business is based on the complex financial transactions. (Pinasti, 2001) argues that the size of a business can encourage a person to think and learn related to the solution of the problems encountered.

\section{METHODOLOGY}

This study used a quantitative approach and based on the data analysis model and categorized as analytical research. Registered Woman Cooperative operating in five local governments, namely: Malang, Blitar, Sidoarjo, Banyuwangi, and Pacitan. The population in this study was all members of the Indonesia Women Cooperative, which amounted to 269 Micro and Small Business workers. All members were divided into four groups based on the business type, i.e. (1) store chain groups, (2) sellers of vegetables, (3) bike repair shop, and (4) beauty place. In this research, there are two groups of micro, small business workers, group which owned shop business, and a group of the vegetable seller. The determination of these two groups was based on the four groups of micro, and small businesses, the group store chain and the vegetable sellers business have bigger members, 53 people in the chain store and 49 people in the group of vegetable sellers. Making a total of 102 respondents. 
This study aimed to test and analyze the causal relationship between exogenous and endogenous variables, as well as to check the validity and reliability of the overall research instrument. Quantitative analysis techniques were used to interpret and analyze data. In accordance with the multidimensional model and tiered with the developed in this study then used Structural Equation Modeling (SEM) analytical techniques by using the AMOS program.

\section{RESULTS}

The structural model was essentially hypothesis testing in this study. There were three types of influences to be presented in the structural model, Direct Effect and Indirect Effect.

Table 1. Results of Hypothesis Testing Direct Effect

\begin{tabular}{|c|c|c|c|c|}
\hline Hypothesis & Influence between Variables & $\begin{array}{c}\text { Path } \\
\text { Coefficient }\end{array}$ & $\begin{array}{c}\text { p- } \\
\text { value }\end{array}$ & Description \\
\hline 1 & $\begin{array}{l}\text { Bookkeeping Training Affects } \\
\text { Financial Record }\end{array}$ & 0,189 & 0,022 & Significant \\
\hline 2 & $\begin{array}{l}\text { The Business Scale affects the } \\
\text { Financial Records }\end{array}$ & 0,197 & 0,029 & Significant \\
\hline 3 & $\begin{array}{l}\text { Bookkeeping Training affects } \\
\text { Member participation }\end{array}$ & 0,296 & 0,001 & Significant \\
\hline 4 & $\begin{array}{l}\text { Business Scale affects Member } \\
\text { participation }\end{array}$ & 0,306 & 0,000 & Significant \\
\hline 5 & $\begin{array}{l}\text { Financial Recording affects } \\
\text { Member Participation }\end{array}$ & 0,491 & 0,000 & Significant \\
\hline
\end{tabular}

According to Table 1, the direct effect shows that the result of the coefficient analysis of the SEM model line of direct influence on training variables and the bookkeeping recording of financial value, obtained by 0.189 with a p-value 0.022 . Because $\mathrm{p}$-value $<5 \%$, hence $\mathrm{H}_{0}$ is rejected, meaning that bookkeeping training has a significant positive effect on the financial recording. The higher the level of bookkeeping training, the higher the financial record of the members of the cooperative.

Education on members about bookkeeping training has been able to increase the activities of the Indonesia Women Cooperative to perform the financial records of its business. Three aspects show this conclusion:

a. education programs in cooperative members had been implemented by Indonesia Women Cooperative in the form of bookkeeping training, as evidenced by the participation of members in bookkeeping training for small and medium businesses,

b. the material presented in the bookkeeping training program had been in accordance with the expectations of Women cooperative members in recording financial business, record daily transactions in daily cash books, accounts receivable and accounts payable, while at the end of the week of listing, its recorded on net sales books and capital changes., and

c. the bookkeeping training program held by Women cooperatives was able to maximize the interest and awareness of the importance of bookkeeping in business.

The result of the coefficient analysis of the SEM model of the direct effect of the variable of Business Scale to Financial Listing obtained by 0,197 with a p-value of 0.029 . Since p-value < $5 \%$, hence $\mathrm{H}_{0}$ is rejected, means that Business Scale has a significant positive effect on Financial Records. The higher the Business Scale level, the higher the Finance Records.

The business scale has a significant positive effect on the Financial Record of members of Indonesia Women Cooperative. This conclusion is based on the reality that members of the Women Indonesia Cooperative as owners, controllers, and users whose also business owners 
have a business scale that must be supported by recording all of their business financial transactions. The higher the Business Scale, the higher the need for recording financial transactions of their business, either daily or weekly transactions.

The results of the SEM model line coefficient analysis showed that the direct variable of bookkeeping training on the member's participation was obtained by 0.296 with p-value was 0.001 . Since $\mathrm{p}$-value $<5 \%$, then $\mathrm{H}_{0}$ is rejected, means that bookkeeping training has a significant positive effect on member participation. The higher level of bookkeeping training resulted in the higher the participation of its members. Bookkeeping training directly affected the participation of the Indonesia Women Cooperative members. The results of these findings can be concluded that bookkeeping training can improve the members' knowledge of financial recording and its participation, especially in financial form.

The result of the coefficient analysis of the SEM model of direct influence with the variable of Business Scale to member participation was obtained by 0,306 with p-value equals to 0.000 . Since $\mathrm{p}$-value $<5 \%$, then $\mathrm{H}_{0}$ is rejected, it means the business scale has a significant positive effect on member participation. The higher the level of business scale of members of Indonesia Women Cooperative, the higher the participation of members to the of Indonesia Women Cooperative. The business scale has a significant positive effect on the participation of Indonesia Women Cooperative members. Business Scale affected the participation of members to be active in all activities held by the cooperative, both activities financial and non-financial. The higher the Business Scale, the higher the member's participation.

The result of coefficient analysis of the SEM model line of the direct influence of the variable of financial recording toward member participation obtained 0,491 with the p-value of 0.000 . Because $p$-value $<5 \%$ then $\mathrm{H}_{0}$ is rejected, means that Financial Recording has a significant positive effect on the participation of members. The higher the Financial Records result, the higher the member's participation. Financial Recording has a significant positive impact on member participation. This conclusion is based on the function of the cooperative, that the cooperative comes from members, is controlled by the members and fully participated for the welfare of the members. If members can see these three functions, then the members' participation can be improved. The active members show the realization of participation of Indonesia Women Cooperative members in the form of economic participation and social participation.

The following are presented indirect effects. 
Table 2. Results of Indirect Hypothesis Testing

\begin{tabular}{|c|c|c|c|c|c|}
\hline \multirow[b]{2}{*}{ Hip } & \multirow[b]{2}{*}{$\begin{array}{c}\text { Influence between } \\
\text { Variables }\end{array}$} & \multicolumn{3}{|c|}{ influences } & \multirow[b]{2}{*}{ conclusions } \\
\hline & & direct & indiret & Total & \\
\hline 6 & $\begin{array}{l}\text { Bookkeeping } \\
\text { training(PK)influence } \\
\text { member participation } \\
\text { (PA) moderated by } \\
\text { Bookkeeping Records } \\
\text { (PP) } \\
\text { a. PK } \rightarrow \text { PA } \\
\text { b. PK } \rightarrow \text { PP } \\
\text { c. PP } \rightarrow \text { PA }\end{array}$ & $\begin{array}{l}0,296 \\
0,189 \\
0,491\end{array}$ & $\begin{array}{c}0.093 \\
- \\
-\end{array}$ & 0,389 & $\begin{array}{l}\text { Financial recording as a } \\
\text { moderator variable } \\
\text { strengthening the effect of } \\
\text { bookkeeping training on } \\
\text { member participation }\end{array}$ \\
\hline 7 & $\begin{array}{l}\text { Business scale(SU) } \\
\text { influence member } \\
\text { participation (MA) } \\
\text { moderated by } \\
\text { bookkeeping } \\
\text { records(PP) } \\
\text { a. SU } \rightarrow \text { MA } \\
\text { b. SU } \rightarrow \text { PP } \\
\text { c. PP } \rightarrow \text { MA }\end{array}$ & $\begin{array}{l}0,306 \\
0.197 \\
0,491\end{array}$ & $\begin{array}{c}0.142 \\
- \\
-\end{array}$ & 0,448 & $\begin{array}{l}\text { Member participation as a } \\
\text { moderator variable that } \\
\text { strengthens the effect of } \\
\text { business scale on member } \\
\text { participation }\end{array}$ \\
\hline
\end{tabular}

Based on Table 2. shows an indirect effect. The indirect impact of bookkeeping training on member participation through Financial Listing has a coefficient value of 0,093 , while the coefficient value of the direct influence of bookkeeping training on member participation amounted to 0,296 , and the total value is 0,389 . Based on these results, the hypothesis stating that Financial Records moderate the influence of member cooperative education on the participation of members can be accepted. These results indicate that Financial Records can strengthen the effect of bookkeeping training on member participation.

Financial Records strengthen the effect of bookkeeping training on Member Participation. The role of active members in the training process cooperative has been able to increase members' understanding of the importance of financial recording and participation into cooperative members. Their understanding will be strengthened by participating in bookkeeping training held by cooperatives so that members know and understand the importance of cooperative members' participation.

The indirect effect of the business scale on the member's participation through Financial Records has a coefficient value of 0.142 , while the value of the coefficient of the direct effect of the Business Scale to member participation is 0.306, and the total value is 0.448. Based on these results, a hypothesis stated that Financial Records moderate the effect of the business scale of members on their participation is acceptable. These results indicate that Financial Records can strengthen the effect of business scale on members' participation.

Financial Records strengthen the influence of Member Scale on Members Participation in the Indonesia Women Cooperative. That is, the participation of members in women cooperative not only because of the business scale, but also the high participation after the financial records of their business transactions both in daily and weekly bookings in accordance with bookkeeping training materials that have been implemented by of Indonesia Women Cooperative. 


\section{DISCUSSION}

Participation of members in of Indonesia Women Cooperative were two forms, non-financial participation, and financial participation. Non-financial participation of the member was following the Annual Members Meeting, attending meetings held by cooperatives, following education and training held by cooperatives, as well as the activeness of members in providing advice, ideas, and input to the cooperative. The participation of members in attending education and training shows that they want an increase in expertise in managing their business. They realize that training will improve their business, especially in the area of bookkeeping and financial reporting. The results of this study support the research from Castro (2015) and Zheng et al. (2012).

Meanwhile, financial participation can be seen from the activity of members in paying principal savings, compulsory savings, voluntary savings, or other savings that can increase the capital owned by the cooperative. The results of this study support the research that has been done of (Georgellis, Y; Joyce, P; Woods, 2000), (Constantinescu, 2015), and (Figueiredo \& Franco, 2018) which stated that there is a real relationship between formal and non-formal education members with the success of cooperatives and learning processes have a positive effect on member's ability and member participation. The participation of members in using services on savings and loan units was almost $100 \%$ of the total number of members. However, from all of the members who borrowed from the cooperative, not all followed the term of the loan.

The Indonesia Women Cooperative members who have small micro businesses have not done the bookkeeping for their business activity. This indicates the absence of financial planning. Without a good financial plan, then someone will tend to waste money that has been earned. Besides, they will also tend to spend money owned by the day. Therefore, bookkeeping training for members of cooperatives is expected to increase member participation, especially in the case of repayment of loans. This bookkeeping training can be used to plan and know the financial condition of the business and cash flow. The effectiveness of training implementation is influenced by the method used in training with the aim that participants can easily absorb the material to improve the knowledge, skills, and attitudes, Amini and Ramezani (2008). Bookkeeping training activities are indispensable for small micro businesses. So it can be said that the majority the participants have small businesses, but in fact, simple bookkeeping is needed to know the cash flow of their business capital. This is in accordance with what was conveyed by Aufar (2013) and Kristiansen (2003).

Perception in persons can influence them in taking a decision. Likewise with Small Micro Businesses became members of the Indonesia Women Cooperative. Their perception that there is no need for financial records should be changed. As the business grows, they realize the need for financial records. Hence, for them, the bigger the business, the more complex the cash flow arrangement of business money, so they need a financial record. Financial Records in Women Cooperatives was a variable that can strengthen the influence of bookkeeping training variables and business scale on members participation. Therefore, for members to participate actively in cooperative activities, financially and non financially, it is necessary to have bookkeeping training on how to record the financial business, both small and medium businesses also perform financial records in managing the business finance. This is in accordance with what was conveyed by Regts (2009).

\section{CONCLUSIONS}

The result of the research shows that: 1) variable of bookkeeping training and business scale for cooperative members have a positive effect on the financial recording; 2) variable of 
bookkeeping training, business scale of member, and financial record have positive effect to members participating in of Indonesia Women Cooperative; and 3) variable of financial recording is a moderator variable that strengthens the influence of training bookkeeping variables and business scale of members participation of Indonesia Women Cooperative.

Referring to the indicators of bookkeeping training, training materials, the frequency of training, and suitability of needs, it shows an increase in member knowledge on how to record their business finances. By understanding bookkeeping, one of the objectives of the training has been fulfilled, the changing behavior and awareness of the members about the importance and benefit of financial recording and participate actively in business activities and decision making in cooperatives. The importance of such financial records is not limited to micro businesses but also small and medium businesses. Therefore, both small and medium enterprises must record their business finances so that they can participate actively in their cooperatives, especially in the financial field.

Based on these findings, it is preferable: (1) Further researchers can use qualitative and developmental approaches so that the problem can be examined in more detail. (2) It is recommended to the Women Cooperative board to assist its members in recording the member's business finances through planned training. (3) The Women Cooperatives can cooperate with the cooperative department and micro, small and medium local businesses, and Universities to assist financial training activities for its members.

\section{References}

Aini, Hafizah, H. A. K., Zuraini, \& Y. (2012). Factors Affecting Cooperatives' Performance in Relation to Strategic Planning and Members' Participation. Procedia-Social and Behavioral Sciences 100-105., 65, 100-105.

Amini, \& Ramezani, M. (2008). Investigating the Success Factors of Poultry Growers' Cooperatives in Iran's Western Provinces. World Applied Sci. J, 5, 81-87.

Aufar. (2013). Faktor-faktor yang mempengaruhi Penggunaan Informasi Akuntansi pada UMKM (survei pada Perusahaan Rekanan PT. PLN di Kota Bandung). Universitas Widyatama.

Bambang Banu, S. (2010). Faktor-faktor Eksternal Perilaku Organisasional anggota Koperasi dan Pengaruhnya terhadap Partisipasi Anggota dan Manfaat Koperasi. Malang.

Birchall, \& Simmons, R. (2004). What Motivates Members to Participate in Cooperatives and Mutual Businesses? Annals of Public and Cooperative Economics, 75(3), 465-495.

Castro, J. L. de, Vilar, R. L. A. de, \& Medeiros, R. G. (2015). Education, ethics, and solidarity in international cooperation. Hist. Cienc. Saude-Manguinhos, 22(1), 143-152. https://doi.org/http://dx.doi.org/10.1590/S010459702015000100008

Constantinescu, L.-A. (2015). Cooperative Spirit in the XXI Century European Cooperative Culture. Procedia Economics and Finance, 27, 199-203. https://doi.org/10.1016/S2212-5671(15)00990-9

Figueiredo, V., \& Franco, M. (2018). Factors influencing cooperator satisfaction: A study applied to wine cooperatives in Portugal. Journal of Cleaner Production, 191, 15-25.

https://doi.org/10.1016/j.jclepro.2018.04.177

Georgellis, Y; Joyce, P; Woods, A. (2000). Entrepreneurial Action, Innovation, and Business Performance: The Small Independent Business. Journal of Small Business and Enterprise Development, 7(1), 7-17.

Harun, \& Mahmood, R. B. (2012). The Relationship between Group Cohesiveness and Performance: An Empirical Study of Cooperatives Movement in Malaysia. International Journal of Cooperative Studies, 1(1), 15-20.

Hassan, A., \& Prakash, D. (1990). Pendidikan Anggota Koperasi. Jakarta: Pusat Latihan dan Penataran Perkoperasian Depertemen Koperasi.

Hendar, \& Kusnadi. (2009). Ekonomi Koperasi. Jakarta: Gramedia.

Huang, C. C., Zazale, S., Othman, R., Aris, N. A., \& Ariff, S. M. M. (2015). Influence of Cooperative Members' Participation and Gender on Performance. Journal of Southeast Asian Research. https://doi.org/10.5171/2015.610199 
Kristiansen S. (2003). Small-scale Business in Rural Java:involution or Innovation? Journal Family Business, 12(1), 21-41.

Nurlela Kataren. (2006). Faktor-faktor yang Mempengaruhi Keberhasilan Koperasi Credit Union dalam Pemberdayaan Masyarakat. Jurnal Harmoni Sosial, 1(3), 14-29.

Osterberg, P., \& Nilsson, J. (2009). Members' Perception of Their Participation in the Governance of Cooperatives: The Key to Trust and Commitment in Agricultural Cooperatives. Agribusiness, 25(2), 181-197.

Pinasti, M. (2001). Penggunaan Informasi Akuntansi dalam Pengelolaan Keuangan Usaha para Pedagang Kecil di Pasar Tradisional Kabupaten Banyumas. Jurnal Ekonomi Bisnis Dan Akuntansi, 3(1), 23-30.

Regts, N. (2009). The Impact of Knowledge and Participation on Cooperative Loyality in Uganda Tanzania (p. 2). p. 2.

Sinaga. (2015). Relationship Between Group Cohesiveness, Achievement Motivation, Entrepreneurship Attitude, Member's Participation Attitude and Cooperative Performance in Bandung Regency Indonesia. PT Persada.

Sungkawati, E., \& Hendrawaty, R. (2018). Accounting Record for SMEs Member of "UBER" Cooperation Talangagung, Malang. IOP Conf. Series: Earth and Environmental Science, 175, 12051. https://doi.org/10.1088/1755-1315/175/1/012051

Sungkawati, E., Prawoto, B., \& Mere, K. (2018). The Business Development of Woman Cooperatives Through Good Corporate Governance and Joint Responsibilty. European Journal of Research and Reflection in Management Sciencess, 6(5).

Sungkawati, E., \& Suarniati, N. W. (2009). Gender-Based Cooperative Educational Program on Woman Cooperative in Blitar Regency. In European Journal of Business and Management (Vol. 7). Retrieved from https://www.iiste.org/Journals/index.php/EJBM/article/view/27518

Zheng, S., Wang, Z., \& Awokuse, T. O. (2012). Determinants of Producers' Participation in Agricultural Cooperatives: Evidence from Northern China. Applied Economic, 2(1). 